\section{Child leukaemia after Chernobyl}

SIR - An increase in the incidence of leukaemia has been suggested as an early hazard of the 1986 Chernobyl nuclear power station disaster ${ }^{1,2}$. This resulted in the exposure to ionizing radiation of 2.3 million inhabitants of the Republic of Belarus, 400,000 of them being children aged $0-14$ years. It has been estimated that many received doses in the range 50-60 millisieverts (ref. 3 ).

The Republican Registry of Blood Diseases in Belarus covers the population of

\begin{tabular}{llcc}
\hline INCIDENCE OF ACUTE LEUKAEMIA IN BYELORUSSIAN \\
\multicolumn{4}{c}{ CHILDREN } \\
\hline $\begin{array}{l}\text { Radionuclide } \\
\text { contamination }\end{array}$ & $\begin{array}{c}\text { Region/ } \\
\text { City }\end{array}$ & $1979-85$ & $1986-91$ \\
Severe & Gomel & 35 & 40 \\
& Mogilev & 48 & 41 \\
Intermediate & Brest & 41 & 40 \\
& Minsk & 35 & 40 \\
Least & Grodno & 36 & 38 \\
& Vitebsk & 39 & 42 \\
& Minsk City & 51 & 48 \\
& All areas & 40.7 & 41.3
\end{tabular}

Age of children: $0-14$; numbers are per million.

the republic, and receives details of cases of childhood leukaemia from haematological and oncological clinics and departments, the Registrar General and autopsies. Diagnoses are based on clinical, cytological (peripheral blood and bone marrow), cytochemical, immunophenotypical and histological data. The registry conforms to international standards of cancer registration. The opportunity has been taken to compare the incidence of childhood leukaemia in Belarus in the period since the Chernobyl accident (1986-91) with that in the preceding period (1979-85).

No appreciable change in the incidence of acute childhood leukaemia in Belarus is seen between the pre-Chernobyl period (40.7 per million) and the subsequent period (41.3) (see table). The same conclusion applies when the sexes are examined separately, males being 47 and 49. respectively, and females 37 and 37 , respectively. These rates are not dissimilar to those recorded in many European countries ${ }^{4}$.

There was considerable variation in the level of radionuclide contamination in different regions of Belarus. However, even those regions with the highest levels of contamination, Gomel and Mogilev, showed no increase in the incidence of acute childhood leukaemia in the later period. Indeed this was slightly lower than in the least contaminated areas of the republic (see table).

Our ongoing work, which is part of the framework of the WHO International Programme on the Health Effects of Chernobyl Accident (IPHECA) and of the European Childhood LeukemiaLymphoma Incidence Study programme (ECLIS), shows that certain predictions of the leukaemogenic effect of the Chernobyl accident have not yet been borne out. However, as carcinogenesis may involve multiple steps and latency periods may be prolonged, depending on the cancer site, further monitoring of the children exposed to radiation is required.

\section{E. P. Ivanov}

G. Tolochko

\section{S. Lazarev}

\section{Shuvaeva}

Research Institute for Haematology and Blood Transfusion,

223059 Minsk, Belarus

1. Ivanov. E. P. et al. Zdravookhr. Belorussii N6, 57-60 (1990). (In Russian.)

2. Ivanov, E. P. Atoms Jap. 37. 24 (1993)

3. Korolev. V.1.Zdravookhr. Belorussii N6. 4-7 (1992). (In Russian.)

Parkin. D. M. et al. Eur. J. Cancer 29A, 85-95 (1993).

\section{Sexual orientation}

SIR - In his article ${ }^{1}$ on our paper ${ }^{2}$ reporting a linkage between Xq28 DNA markers and male sexual orientation, Maddox conjectures that the $\mathrm{Xq} 28$ locus might influence sexual orientation by making the mothers of gay men "over-loving", in which case "the gene concerned would be strictly irrelevant to the causation of male homosexuality, whose determinants would remain those of nurture rather than nature." In other words, the gene is postulated to act in women rather than in men.

This speculation violates Mendel's law of independent assortment. Suppose that there were an $\mathrm{Xq} 28$-linked gene $\mathrm{X}^{*}$ that caused women of genotype $\mathrm{X} 1 * / \mathrm{X} 2$ and/or of genotype $\mathrm{X} 1^{*} / \mathrm{X} 2 *$ to be "over-loving" and therefore more likely than average to have gay sons. In both cases, all of the sons, either homosexual or heterosexual, would have exactly the same 50 per cent chance of inheriting either the X1 or the $\mathrm{X} 2$ markers. Therefore, in contrast to our experimental findings, no linkage between sexual orientation in males and Xq28 DNA markers would have been observed. One might observe linkage between sisters who have gay sons, but this was not analysed in our study.

Second, Maddox suggests that the study would have been more convincing if we had measured the "incidence of the inheritance of the X-linked markers in the general population". But such population-based studies require association; that is, a correlation between the trait and a particular allele among unrelated individuals. What we measured (as should be evident from the title of the paper) was linkage; that is, a correlation between the trait and a locus among related individuals. The differences between association and linkage, and between alleles and loci, are wellestablished concepts in genetics.

\section{Dean Hamer}

Laboratory of Biochemistry,

National Cancer Institute,

National Institutes of Health.

Bethesda,

Maryland 20892, USA

SIR - In commenting on the recent report of genetic linkage between markers on the $\mathrm{X}$ chromosome and male homosexuality ${ }^{2}$, Maddox proposes the possibility that the putative $\mathrm{X}$-linked gene could play a role in determining whether a mother is "overloving" rather than contributing directly to homosexual behaviour ${ }^{1}$. While this hypothesis is consistent with the observed maternal inheritance pattern of homosexuality, it is clearly contradicted by the linkage data.

If the gene were to affect the behaviour of the mother rather than that of the sons, then brothers, maternal uncles and maternal cousins of homosexuals would still show higher rates of homosexuality than controls as they would be more likely to have had "over-loving" mothers. But because the gene would have no direct effect on the sons, a pair of brothers would be no more likely to inherit the same allele than different alleles from their mother, and hence would show no linkage of the kind observed. It is only when the presence of one allele directly affects male sexual orientation that two brothers would be more likely than chance to share it. If the linkage reported by Hamer et al. is confirmed, the gene or genes involved must, regardless of their actual function, influence the behaviour of the males rather than their mothers.

\section{Kruglyak}

Whitehead Institute for Biomedical

Research,

9 Cambridge Center, Cambridge, Massachusetts 02142, USA

1. Maddox, J. Nature 364, 281 (1993).

2. Hamer D. H. Hu, S. Magnuson, V. L., Hu, N. \& Pattatucci. A. M. L. Science 261, 321-327 (1993).

MADDOX WRITES - My original purpose was to draw attention to the interest of a study seeming to be the first identification of a behavioural gene in human beings. I believe it unwise, when breaking such new ground, to settle for the simplest interpretation of the linkage data when two previous such interpretations (published in this journal) have proved unfounded. And should not even molecular geneticists, when announcing new linkages, explain where other research (as on the behaviour of gay men's mothers) fits in?

NATURE · VOL 365 - 21 OCTOBER 1993 